\title{
Study regarding team statistics at the last three men's basketball World Championship
}

\author{
Adrian Gheorghe PETREANU1, Manuela PETREANU²
}

\begin{abstract}
Achieving superior performance parameters in major competitions has highlighted a number of issues that characterize the current basketball game practiced by the best teams in the world. Depending on the height, role, importance and the effectiveness of players on their positions, specific models are to be observed in the case of senior teams [1].

In this paper we present a comparative study regarding the parameters' models in the men's basketball games during the World Championships in Japan - 2006, in Turkey - 2010 and in Spain - 2014. Along with data interpretation, we tried to effectively bring our scientific contribution in shaping a model significant for the international basketball games, useful for the specialists in the field. Centralization of the statistical data used in our study was useful in calculating the averages for each game parameter and the increasing value for each tournament, managing to achieve a precise statistical comparison. The values encountered in this comparative research showed growth or regression trends for the game parameters. In conclusion, trends of progress or regress, referring to the statistical model parameters involved in the game, pragmatically showed, that in the game of basketball - training is the key to success.
\end{abstract}

Key words: Basketball, Team, Statistics, Comparison

\section{Rezumat}

Obținerea unor performanțe la parametrii superiori în marile competiţii a scos în evidență o serie de aspecte ce caracterizează jocul de baschet actual, practicat de cele mai bune echipe din lume. În funcţie de statura, rolul, importanţa şi eficacitatea jucătorilor pe posturi, se pot observa modele specifice în cadrul echipelor de seniori [1].

În acestă lucrare prezentăm un studiu comparativ al parametrilor modelului de joc la Campionatele Mondiale de baschet masculin din Japonia 2006, Turcia 2010 şi Spania 2014. Odată cu interpretarea datelor, încercăm să ne aducem contribuția într-un mod cât mai stiințific și eficient la profilarea unui model de joc internațional, util specialiștilor în domeniu.

Centralizarea datelor statistice utilizate în studiul nostru ne-au fost utile în calcularea mediilor pentru fiecare parametru de joc, cât şi în calcularea procentului de creștere pentru fiecare campionat în parte, reuşind asfel să realizăm o comparaţie matematico-statistică exactă. Valorile întâlnite în cadrul studiului comparativ de față, arată tendinţele de creştere sau regresie a valorilor indicatorilor statistici, a parametrilor modelului de joc.

În concluzie, tendinţele de progres sau de regres, referindu-ne aici la statistica parametrilor modelului de joc, observați în cadrul studiului nostru, arată în cel mai pragmatic mod, că în jocul de baschet - pregatirea este cheia succesului.

Cuvinte cheie: Baschet, Echipă, Statistică, Comparatie

\footnotetext{
${ }^{1}$ Assistant professor, PhD, Physical Education and Sports Discipline, University Of Medicine and Pharmacy „Carol Davila”Bucharest, email: adrian.petreanu@yahoo.com

2Assistant professor PhD, Physical Education and Sports Discipline, University Of Medicine and Pharmacy „Carol Davila”Bucharest
} 


\section{Introduction}

Performance analysis in basketball is currently an essential tool for coaches and technical staff. This analysis method allows them to collect reliable information about their opponents, competition, as well as their own team [2]

Basketball has been one of the most studied sports through international analysis.

Game-related statistics are very popular among coaches, players and researchers and have been used to improve the understanding of game performance in different contexts [3]. The investigation in this area has been traditionally focused on men's basketball teams [4].

The spectacular game of basketball unfolds through the alternation of the attack and defense phases, but the beauty of the game is given by the precision of the field goals. Scoring baskets for 3 points, 2 points and free throws in certain game situations makes thousands of spectators stand up and cheer.

The game statistics for the model parameters, represented by computer recordings during the game, are a great way of evaluating the players on the team and their positions in game. Consequently coaches will have direct information on the evolution of the team during the game, at rest-time, half-time, as well as after the game.

We may also obtain data on height, weight and age of the players in the Olympic Games, World Championships, European Championships, Euroleague Competitions, National and International Championships, data that will be prevalent for each position on the field.

These information are obtained for all age and gender groups, resulting in the average height and weight, parameters that are in close relation with the players' positions in the game center/forward/guard.

\section{Aim and purpose of the study}

The purpose of the research is to develop a qualitative and quantitative assessment of the game for the men's basketball teams that participated in the World Championships, which were included in the study.

The game parameters and patterns, which will be analyzed in this study (a comparison between the three World Championships), are represented by the following:

- Free-throws - FT \%;

- 2 point field goals $-2 \mathrm{P} \%$;

- 3 point field goals - 3P \%;

- Rebounds per game - RPG

- Offensive rebounds - $\mathrm{R}$ of;

- Defensive rebounds - R def;

- Assists - APG;

- Fouls - PFPG;

- Steals - STLPG;

- Blocks - BLKPG;

- Turnovers - TOPG

- Points per game - PPG;

- Total points - TOTP;

This complex palette of statistics that characterize the game (the abovementioned 13 parameters) has a big importance and is necessary to be taken in consideration in optimizing the strategy of training, regardless the competition levels of the teams.

\section{Material and method}

To obtain a more accurate comparison we used a number of research methods specific for physical education and sports, which together with the statistical and mathematical methods, constituted the basis of our study.

An important role in our study was the documentation method and the study of the available literature in the field. The large volume of information was collected from official competitions websites [7], and studies were statistically analyzed and summarized in Tables I, II and III. 
Table I. Statistical data - parameters of the game at WC Basket men - Japan 2006

\begin{tabular}{|c|c|c|c|c|c|c|c|c|c|c|c|c|c|}
\hline $\begin{array}{l}\text { Country } \\
\text { Average } \\
\text { height }\end{array}$ & $1 \mathrm{p} \%$ & $2 \mathrm{p} \%$ & $3 p \%$ & Rof & Rdef & $\mathrm{R} / \mathrm{G}$ & Asist/G & Fouls/G & Stil & Block/G & PPG & TOG & TOTP \\
\hline $\begin{array}{l}\text { 1. Spain } \\
200 \mathrm{~cm}\end{array}$ & 71 & 56,9 & 37,4 & 86 & 249 & 37 & 14,3 & 16,7 & 9,8 & 2,9 & 88,6 & 14,3 & 797 \\
\hline $\begin{array}{l}\text { 2. Greece } \\
202 \mathrm{~cm} \\
\end{array}$ & 70 & 56 & 32,9 & 78 & 178 & 28 & 12,2 & 20,1 & 10 & 2,4 & 80 & 14,8 & 720 \\
\hline $\begin{array}{l}\text { 3. USA } \\
201 \mathrm{~cm}\end{array}$ & 66,7 & 57,5 & 36,9 & 126 & 224 & 39 & 18,8 & 19,9 & 11 & 4,9 & 104 & 10,8 & 932 \\
\hline $\begin{array}{l}\text { 4. Argentina } \\
200 \mathrm{~cm}\end{array}$ & 73,6 & 54,6 & 35,4 & 107 & 249 & 40 & 18,1 & 20 & 7,1 & 2,1 & 86,8 & 13,4 & 781 \\
\hline $\begin{array}{l}\text { 5. France } \\
199 \mathrm{~cm} \\
\end{array}$ & 63,5 & 45,3 & 27,3 & 110 & 246 & 40 & 10,8 & 19,6 & 7,2 & 3,7 & 68,4 & 14,7 & 616 \\
\hline $\begin{array}{l}\text { 6. Turkey } \\
201 \mathrm{~cm}\end{array}$ & 63,8 & 46,7 & 34,8 & 92 & 213 & 34 & 11,9 & 25,1 & 7,3 & 3,4 & 74,3 & 16,6 & 669 \\
\hline $\begin{array}{l}\text { 7. Lithuania } \\
201 \mathrm{~cm}\end{array}$ & 64 & 54,8 & 30,8 & 103 & 249 & 39 & 15,3 & 23,7 & 9 & 2,6 & 79,1 & 20,9 & 712 \\
\hline $\begin{array}{l}\text { 8. Germany } \\
198 \mathrm{~cm}\end{array}$ & 79 & 48,8 & 34,4 & 95 & 245 & 38 & 12,7 & 21,1 & 5 & 2 & 77,7 & 16,9 & 699 \\
\hline $\begin{array}{l}\text { 9. Angola } \\
194 \mathrm{~cm}\end{array}$ & 73,3 & 48,2 & 36,9 & 78 & 154 & 39 & 14,3 & 23,3 & 8,3 & 2,5 & 85,5 & 12,3 & 513 \\
\hline $\begin{array}{l}\text { 10. Australia } \\
200 \mathrm{~cm}\end{array}$ & 65,5 & 50,5 & 38,6 & 45 & 148 & 32 & 15,2 & 21,2 & 8,7 & 1,5 & 73,8 & 20,8 & 443 \\
\hline $\begin{array}{l}\text { 11. China } \\
204 \mathrm{~cm}\end{array}$ & 80,7 & 50,9 & 37,4 & 61 & 146 & 35 & 13,3 & 22,3 & 3 & 4,3 & 81,3 & 17,3 & 488 \\
\hline $\begin{array}{l}12 . \text { Italy } \\
199 \mathrm{~cm}\end{array}$ & 66,4 & 47,3 & 35,6 & 70 & 137 & 35 & 14,7 & 25 & 7,5 & 2 & 75,7 & 12,2 & 454 \\
\hline $\begin{array}{l}13 . \text { New Z. } \\
197 \mathrm{~cm}\end{array}$ & 65 & 51,4 & 28,5 & 52 & 132 & 31 & 14,3 & 23,7 & 8,5 & 1 & 67,8 & 16,5 & 407 \\
\hline $\begin{array}{l}\text { 14. Nigeria } \\
200 \mathrm{~cm}\end{array}$ & 59,3 & 44,5 & 29,5 & 80 & 134 & 36 & 10 & 20,3 & 9 & 2,3 & 74,7 & 11,7 & 448 \\
\hline $\begin{array}{l}\text { 15. Ser\& M. } \\
202 \mathrm{~cm}\end{array}$ & 75,2 & 49,3 & 40,4 & 60 & 144 & 34 & 12,8 & 23 & 7,3 & 5 & 80,7 & 13,3 & 484 \\
\hline $\begin{array}{l}\text { 16. Slovenia } \\
200 \mathrm{~cm}\end{array}$ & 67,9 & 48 & 44,7 & 82 & 153 & 39 & 14,8 & 23,3 & 7,3 & 2,7 & 86,3 & 16,3 & 518 \\
\hline $\begin{array}{l}\text { 17. Brazil } \\
202 \mathrm{~cm}\end{array}$ & 61,9 & 51,1 & 28,8 & 54 & 97 & 30 & 14 & 22,6 & 10 & 2 & 79,8 & 15 & 399 \\
\hline $\begin{array}{l}\text { 18. Japan } 194 \\
\text { cm }\end{array}$ & 67,1 & 45,6 & 31,6 & 28 & 105 & 27 & 10,4 & 23 & 7 & 1,4 & 64,4 & 15 & 322 \\
\hline $\begin{array}{l}\text { 19. Lebanon } \\
196 \mathrm{~cm}\end{array}$ & 73,9 & 46,7 & 28,2 & 52 & 106 & 32 & 9,2 & 18,8 & 6,6 & 2,6 & 71,4 & 19,2 & 357 \\
\hline $\begin{array}{l}\text { 20. Puerto R. } \\
199 \mathrm{~cm}\end{array}$ & 70,3 & 45,6 & 51 & 42 & 126 & 34 & 12,2 & 23,2 & 6,4 & 2 & 86,4 & 14,4 & 432 \\
\hline $\begin{array}{l}\text { 21. Panama } \\
197 \mathrm{~cm}\end{array}$ & 54,6 & 43,4 & 24,1 & 69 & 113 & 36 & 8,4 & 21,2 & 6,6 & 2 & 65,2 & 19,2 & 326 \\
\hline $\begin{array}{l}\text { 22. Qatar } \\
198 \mathrm{~cm}\end{array}$ & 58,2 & 42,7 & 35,7 & 54 & 105 & 32 & 13 & 20,2 & 7,8 & 1,6 & 62 & 26,6 & 310 \\
\hline $\begin{array}{l}\text { 23. Senegal } \\
202 \mathrm{~cm}\end{array}$ & 69,5 & 42,3 & 35,1 & 61 & 125 & 37 & 12,2 & 22,8 & 7,8 & 2,6 & 71 & 16,8 & 355 \\
\hline $\begin{array}{l}\text { 24. Venezuela } \\
200 \mathrm{~cm}\end{array}$ & 60,2 & 41 & 28,7 & 70 & 116 & 37 & 11 & 19,4 & 6,6 & 3 & 67,2 & 18,4 & 336 \\
\hline
\end{tabular}


Table II. Statistical data - parameters of the game at WC Basket men WC Basket men - Turkey 2010

\begin{tabular}{|c|c|c|c|c|c|c|c|c|c|c|c|c|c|}
\hline $\begin{array}{l}\text { Country } \\
\text { average height }\end{array}$ & $1 \mathrm{p} \%$ & $2 \mathrm{p} \%$ & $3 p \%$ & Rof & Rdef & $\mathrm{R} / \mathrm{G}$ & Asist/G & Fouls/G & Stil & Block/G & PPG & TOG & TOTP \\
\hline $\begin{array}{l}\text { 1. USA } \\
196 \mathrm{~cm} \\
\end{array}$ & 73,3 & 56,7 & 38,5 & 117 & 258 & 42 & 18,2 & 19 & 10,4 & 4 & 92,8 & 12 & 835 \\
\hline $\begin{array}{l}\text { 2.Turkey } \\
200 \mathrm{~cm} \\
\end{array}$ & 60,1 & 53,5 & 42,9 & 85 & 241 & 36 & 16,6 & 17,9 & 8,1 & 3,4 & 81,1 & 11,7 & 730 \\
\hline $\begin{array}{l}\text { 3.Lithuania } \\
201 \mathrm{~cm}\end{array}$ & 73,5 & 52,4 & 38 & 97 & 243 & 38 & 14,4 & 20,7 & 5,7 & 2,8 & 82,9 & 13,1 & 746 \\
\hline $\begin{array}{l}\text { 4. Serbia } \\
204 \mathrm{~cm} \\
\end{array}$ & 74,6 & 56,1 & 39,6 & 96 & 235 & 37 & 18,1 & 20,3 & 6,9 & 2,1 & 88,9 & 12,7 & 800 \\
\hline $\begin{array}{l}5 . \text { Argentina } \\
199 \mathrm{~cm}\end{array}$ & 73,4 & 53,3 & 38,7 & 81 & 224 & 34 & 15,4 & 19,1 & 7,3 & 1,3 & 83,3 & 10,4 & 750 \\
\hline $\begin{array}{l}\text { 6. Spain } \\
200 \mathrm{~cm}\end{array}$ & 71,8 & 56,3 & 36,7 & 91 & 244 & 37 & 18,2 & 21,4 & 7,4 & 4,9 & 85,2 & 13,6 & 767 \\
\hline $\begin{array}{l}\text { 7. Russia } \\
203 \mathrm{~cm}\end{array}$ & 80,1 & 50,8 & 34,6 & 85 & 233 & 35 & 16 & 21,4 & 5,8 & 3,8 & 74 & 14,8 & 666 \\
\hline $\begin{array}{l}\text { 8. Slovenia } \\
201 \mathrm{~cm}\end{array}$ & 74,9 & 53,9 & 35,6 & 89 & 217 & 34 & 13,2 & 23,3 & 6,9 & 1,3 & 78,4 & 13,3 & 706 \\
\hline $\begin{array}{l}\text { 9. Brazil } \\
199 \mathrm{~cm} \\
\end{array}$ & 74 & 52,6 & 39,5 & 55 & 137 & 32 & 14,3 & 20,3 & 8,2 & 1,7 & 81,2 & 12 & 487 \\
\hline $\begin{array}{l}\text { 10. Australia } \\
200 \mathrm{~cm}\end{array}$ & 72,3 & 53,1 & 29,9 & 58 & 154 & 35 & 13 & 18,8 & 7 & 2,3 & 73,2 & 13 & 439 \\
\hline $\begin{array}{l}\text { 11. Greece } \\
204 \mathrm{~cm}\end{array}$ & 65,6 & 55,2 & 33,1 & 73 & 149 & 37 & 14,7 & 21 & 7,7 & 2,7 & 79,2 & 10,8 & 475 \\
\hline $\begin{array}{l}12 . \text { New Zealand } \\
196 \mathrm{~cm}\end{array}$ & 73,6 & 50,7 & 33,1 & 75 & 128 & 34 & 16 & 24,7 & 7,3 & 1 & 80 & 13,2 & 480 \\
\hline $\begin{array}{l}\text { 13. France } \\
198 \mathrm{~cm}\end{array}$ & 73,6 & 50,3 & 37,8 & 54 & 136 & 32 & 15,7 & 20,8 & 7 & 3 & 71,3 & 16,2 & 428 \\
\hline $\begin{array}{l}\text { 14. Croatia } \\
200 \mathrm{~cm}\end{array}$ & 67,4 & 51,4 & 36,2 & 76 & 130 & 34 & 12,5 & 23,8 & 6,2 & 1,7 & 77,8 & 12 & 467 \\
\hline $\begin{array}{l}15 . \text { Angola } \\
196 \mathrm{~cm}\end{array}$ & 62,9 & 46,6 & 29,7 & 65 & 124 & 32 & 10,5 & 19,5 & 6,7 & 1,8 & 67,7 & 14,3 & 406 \\
\hline $\begin{array}{l}\text { 16. China } \\
204 \mathrm{~cm}\end{array}$ & 72,7 & 42,6 & 35,8 & 55 & 148 & 34 & 10,7 & 17,7 & 5,8 & 2,7 & 71,2 & 13,5 & 427 \\
\hline $\begin{array}{l}\text { 17. Germany } \\
200 \mathrm{~cm}\end{array}$ & 76,6 & 47,2 & 40,5 & 37 & 129 & 33 & 13,6 & 21,8 & 5,6 & 2,8 & 75,6 & 15,8 & 378 \\
\hline $\begin{array}{l}\text { 18. Puerto Rico } \\
199 \mathrm{~cm}\end{array}$ & 69,6 & 51,7 & 32,2 & 52 & 150 & 40 & 15,8 & 22 & 4 & 3,4 & 77,2 & 12,8 & 386 \\
\hline $\begin{array}{l}\text { 19. Iran } \\
198 \mathrm{~cm}\end{array}$ & 70,4 & 45,6 & 24,2 & 61 & 112 & 35 & 7,8 & 16,6 & 7,6 & 3,2 & 60,2 & 18,4 & 301 \\
\hline $\begin{array}{l}\text { 20. Lebanon } \\
197 \mathrm{~cm} \\
\end{array}$ & 63,9 & 44,3 & 33,3 & 54 & 96 & 30 & 10,6 & 16,2 & 7,8 & 1,2 & 67,8 & 16,8 & 339 \\
\hline $\begin{array}{l}\text { 21.Cote d'Ivoire } \\
198 \mathrm{~cm}\end{array}$ & 67 & 40,1 & 30,2 & 59 & 120 & 36 & 10,6 & 20,6 & 8,4 & 4,8 & 66,8 & 14,6 & 334 \\
\hline $\begin{array}{l}\text { 22. Canada } \\
200 \mathrm{~cm}\end{array}$ & 67,4 & 41,8 & 31,5 & 55 & 109 & 33 & 10,6 & 20,6 & 7,6 & 3 & 66 & 12,2 & 330 \\
\hline $\begin{array}{l}\text { 23. Jordan } \\
199 \mathrm{~cm}\end{array}$ & 68,2 & 49,1 & 33,6 & 63 & 113 & 35 & 12,2 & 19,6 & 4,8 & 1 & 72,2 & 15,4 & 361 \\
\hline $\begin{array}{l}\text { 24. Tunisia } \\
200 \mathrm{~cm}\end{array}$ & 68,5 & 36,9 & 28,4 & 74 & 106 & 36 & 8,4 & 16 & 6,8 & 3,2 & 60 & 15,2 & 300 \\
\hline
\end{tabular}


Table III. Statistical data - parameters of the game at WC Basket men - Spain 2014

\begin{tabular}{|c|c|c|c|c|c|c|c|c|c|c|c|c|c|}
\hline $\begin{array}{l}\text { Country } \\
\text { average height }\end{array}$ & $1 \mathrm{p} \%$ & $2 \mathrm{p} \%$ & $3 p \%$ & Rof & Rdef & $\mathrm{R} / \mathrm{g}$ & Asist/G & Fouls/G & Stil & Block/G & PPG & TOG & ТОТР \\
\hline $\begin{array}{l}\text { 1. USA } \\
201 \mathrm{~cm}\end{array}$ & 71,4 & 57 & 40,1 & 135 & 268 & 45 & 20,4 & 19,8 & 12,1 & 5,6 & 105 & 13,7 & 941 \\
\hline $\begin{array}{l}\text { 2. Serbia } \\
204 \mathrm{~cm}\end{array}$ & 69,5 & 55,8 & 37 & 79 & 210 & 32 & 16,8 & 22,3 & 6,2 & 1,6 & 83 & 11,9 & 743 \\
\hline $\begin{array}{l}\text { 3. Franta } \\
201 \mathrm{~cm}\end{array}$ & 71,2 & 58,8 & 34,1 & 75 & 238 & 35 & 16 & 20,1 & 5,2 & 2,6 & 77 & 13,8 & 690 \\
\hline $\begin{array}{l}\text { 4. Lituania } \\
202 \mathrm{~cm}\end{array}$ & 77 & 50,7 & 37,1 & 90 & 228 & 35 & 12,3 & 19 & 4 & 3,3 & 77 & 14,6 & 693 \\
\hline $\begin{array}{l}\text { 5. Spania } \\
200 \mathrm{~cm}\end{array}$ & 76,2 & 58,8 & 30,2 & 63 & 203 & 38 & 18 & 18,1 & 8,6 & 5,9 & 83 & 11,6 & 581 \\
\hline $\begin{array}{l}\text { 6. Brazilia } \\
200 \mathrm{~cm}\end{array}$ & 61,8 & 53,8 & 37,3 & 72 & 199 & 39 & 15,7 & 19,6 & 7,9 & 2,4 & 80 & 10,3 & 557 \\
\hline $\begin{array}{l}\text { 7. Slovenia } \\
200 \mathrm{~cm}\end{array}$ & 70,5 & 58,7 & 35,3 & 79 & 153 & 33 & 13,6 & 23,4 & 6,6 & 2,1 & 82 & 15,1 & 572 \\
\hline $\begin{array}{l}\text { 8. Turkey } \\
201 \mathrm{~cm}\end{array}$ & 68,6 & 47,5 & 31,7 & 66 & 183 & 36 & 15,4 & 19 & 6,7 & 3,4 & 70 & 14,4 & 491 \\
\hline $\begin{array}{l}\text { 9. Grecia } \\
204 \mathrm{~cm}\end{array}$ & 75,7 & 55,3 & 35 & 53 & 179 & 39 & 17,7 & 22,8 & 5,8 & 4,2 & 81 & 12,8 & 486 \\
\hline $\begin{array}{l}\text { 10. Croatia } \\
203 \mathrm{~cm}\end{array}$ & 73,7 & 52,8 & 34 & 53 & 159 & 35 & 16 & 22,7 & 5,3 & 1,8 & 80 & 14,3 & 478 \\
\hline $\begin{array}{l}\text { 11. Argentina } \\
198 \mathrm{~cm}\end{array}$ & 73,7 & 48,8 & 38 & 49 & 150 & 33 & 16,5 & 20,8 & 6,5 & 1,2 & 81 & 9,2 & 485 \\
\hline $\begin{array}{l}\text { 12. Australia } \\
201 \mathrm{~cm}\end{array}$ & 68,9 & 48,1 & 47,9 & 76 & 143 & 37 & 17 & 20 & 6,3 & 1,5 & 78 & 16,3 & 468 \\
\hline $\begin{array}{l}\text { 13. Rep. Dom } \\
195 \mathrm{~cm}\end{array}$ & 63 & 46,7 & 33,6 & 65 & 173 & 40 & 13,5 & 19,7 & 5,7 & 3 & 68 & 18 & 408 \\
\hline $\begin{array}{l}\text { 14. Mexic } \\
197 \mathrm{~cm}\end{array}$ & 66,1 & 51,4 & 38,3 & 73 & 138 & 35 & 12,7 & 18,8 & 5,7 & 2,5 & 72 & 15,3 & 433 \\
\hline $\begin{array}{l}\text { 15. New Zealand } \\
196 \mathrm{~cm}\end{array}$ & 67,4 & 46,6 & 30,9 & 91 & 147 & 40 & 13,5 & 20,8 & 4,2 & 1,3 & 70 & 16,3 & 418 \\
\hline $\begin{array}{l}\text { 16. Senegal } \\
202 \mathrm{~cm}\end{array}$ & 70,5 & 45,2 & 27,4 & 64 & 142 & 34 & 12 & 22 & 8,8 & 4,7 & 67 & 16,7 & 404 \\
\hline $\begin{array}{l}\text { 17. Angola } \\
196 \mathrm{~cm}\end{array}$ & 73,3 & 45,3 & 30,3 & 83 & 119 & 40 & 13,4 & 19,4 & 8 & 1,4 & 75 & 13 & 375 \\
\hline $\begin{array}{l}\text { 18. Ukraine } \\
200 \mathrm{~cm}\end{array}$ & 73,8 & 44,6 & 35,2 & 42 & 124 & 33 & 12,4 & 19,4 & 5,8 & 1,4 & 69 & 15,6 & 344 \\
\hline $\begin{array}{l}\text { 19. Poerto Rico } \\
198 \mathrm{~cm} \\
\end{array}$ & 75 & 42,6 & 39,3 & 53 & 107 & 32 & 11 & 24,8 & 6,6 & 1,2 & 78 & 15 & 388 \\
\hline $\begin{array}{l}20 . \text { Iran } \\
198 \mathrm{~cm} \\
\end{array}$ & 71,4 & 50,2 & 32,6 & 54 & 102 & 31 & 12,2 & 22,2 & 9,6 & 1,4 & 69 & 19,2 & 344 \\
\hline $\begin{array}{l}\text { 21. Philippines } \\
191 \mathrm{~cm}\end{array}$ & 79,6 & 44,8 & 32,6 & 54 & 141 & 39 & 10,8 & 21,4 & 7,4 & 1,8 & 77 & 16 & 383 \\
\hline $\begin{array}{l}\text { 22. Finlanda } \\
199 \mathrm{~cm}\end{array}$ & 74,4 & 40,9 & 35,5 & 43 & 105 & 30 & 13 & 24,6 & 7,4 & 2 & 68 & 15,8 & 342 \\
\hline $\begin{array}{l}\text { 23. Korea } \\
194 \mathrm{~cm}\end{array}$ & 74 & 49,7 & 26,5 & 39 & 90 & 26 & 15,8 & 18,4 & 4,6 & 6,6 & 63 & 14,2 & 316 \\
\hline $\begin{array}{l}\text { 24. Egipt } \\
196 \mathrm{~cm}\end{array}$ & 61 & 41,9 & 28 & 48 & 94 & 28 & 10,2 & 19,8 & 6,8 & 1,4 & 62 & 16 & 311 \\
\hline
\end{tabular}

We extracted statistical information for the 13 game parameters from all 24 teams participating in a World Championship, summed up in 72 teams (3 World Championships). The games officially played by the 72 teams in the three editions of the World Championship added up to a number of 228 games, and also underwent statistical analysis.

Figures expressed in this specific format can be summed up in a table summarizing the data useful in the analysis of objective statistical models for the game parameters.

Based on the information we gathered and used in the performance (table IV), we propose an efficient comparison of both the statistical and mathematical significance, in order to determine the current trends in world basketball, and to identify the tendencies of progression or regression of certain parameters. 
Table IV. Comparing averages and augmentation rate with reference to the parameters of the game

\begin{tabular}{ccccccc}
\hline $\begin{array}{c}\text { The statistical } \\
\text { parameters }\end{array}$ & $\begin{array}{c}\text { Average } \\
2006\end{array}$ & $\begin{array}{c}\text { Average } \\
2010\end{array}$ & $\begin{array}{c}\text { Average } \\
2014\end{array}$ & $\begin{array}{c}\text { Augmentation } \\
\text { rate \% } \\
(2010 \mathrm{vs} 2006)\end{array}$ & $\begin{array}{c}\text { Augmentation } \\
\text { rate \% } \\
(2014 \mathrm{vs} 2010)\end{array}$ & $\begin{array}{c}\text { Augmentation } \\
\text { rate } \%\end{array}$ \\
\hline FT $\%$ & 67,53 & 70,64 & 71,15 & $\underline{4,62}$ & 0,73 & $\underline{5,37}$ \\
\hline 2P $\%$ & 48,71 & 49,68 & 49,83 & 1,98 & 0,32 & $\underline{2,30}$ \\
\hline 3P $\%$ & 34,36 & 34,73 & 34,50 & 1,08 & $-0,68$ & 0,39 \\
\hline R off & 73,13 & 71,13 & 66,63 & $-2,74$ & $-6,33$ & $-8,89$ \\
\hline R def & 162,25 & 164,00 & 158,13 & 1,08 & $-3,58$ & $-2,54$ \\
\hline RPG & 34,94 & 35,01 & 35,19 & 0,20 & 0,51 & 0,72 \\
\hline APG & 13,08 & 13,63 & 14,41 & $\underline{4,21}$ & $\underline{5,75}$ & $\underline{10,19}$ \\
\hline PFPG & 21,65 & 20,13 & 20,79 & $-7,01$ & $-3,27$ & $-3,97$ \\
\hline STLPG & 7,70 & 6,96 & 6,74 & $-9,68$ & $-3,11$ & $-12,49$ \\
\hline BLKPG & 2,60 & 2,63 & 2,68 & 0,96 & 1,90 & $\underline{2,88}$ \\
\hline PPG & 77,15 & 75,58 & 75,53 & $-2,04$ & $-0,08$ & $-2,11$ \\
\hline TOPG & 16,14 & 13,66 & 14,55 & $-15,38$ & $\underline{6,50}$ & $-9,89$ \\
\hline TOTP & 521,58 & 514,08 & 485,46 & $-1,44$ & $-5,57$ & $-6,93$ \\
\hline
\end{tabular}

The augmentation rate represents the medium progress [5] expressed in percentages, but can also be the progress or regress rate, and was calculated using the formula:

The augmentation rate $=$ the difference between averages (X Tf $-\mathrm{X} \mathrm{Ti}$ ) / X Ti $* 100$. In our case the initial and final data were the three editions of World Championship used one after the other (table IV).

\section{Results}

The first parameter from the literature review refers to the average height of each team participating in these three editions of the World Championships of Basketball included in the study.

From these data we can observe that the averages of height on each issue separately, present no significant differences:

- $\quad$ The 2006 Edition - 199,41 cm;

- $\quad$ The 2010 Edition - 199,62 cm;

- $\quad$ The 2014 Edition - 199,04 cm;

In reference to the average height and rankings in the overall standings, we can assert that for the first three places, except USA-representative team (The 2010 Edition - $196 \mathrm{~cm}$ ), all participants have a height average above the average calculated for all the editions of the championships that we studied.

Also for these criteria (average height) we calculated the average height, by grouping them into three categories, according to the geographical affiliation. The European continent, represented by 29 teams, has an average height of $200.90 \mathrm{~cm}$, America's 17 team has an average of $198.86 \mathrm{~cm}$, and the rest of the continents (26 teams) were grouped in the same category, and have an average height of $197.87 \mathrm{~cm}$.
We note that Europe has the highest number of teams in the competition and therewith, the biggest average height.

In Tables I, II and III, in which we presented all the 13 parameters included in the studies, the findings correlate with the ranking of each team at the end of the competition.

Using observation methods, we can assert that the best results are achieved through the statistical model parameters of the leading teams.

Analyzing and centralizing information in the tables 1,2 , and 3 we can notice that in Japan (2006): the first place has ranked highest in only 2 of the 13 game parameters. The third place had 8 of the 13 best results, while teams ranked IV, V, VII and XI only have one. This can be explained by the fact that during that time (2006) the game of basketball was not as pragmatic as it is nowadays.

During the World Basketball Championship in Turkey (2010) the situation is totally different: the team that came first, also, has the best indicators in 8 out of 13 parameters; places II, IV, VII and XXIV have only 1 , while the sixth place has two best results among the 13 parameters taken into account in our study.

Basically, in Spain (2014), there are no big changes in comparison with the previous edition, as it follows: first place obtained 7 of the 13 best results; Places III, IV, XI and XII have 1 of the best results.

We can now assert that in order to get a good ranking in a championship, a basketball team must also rank the highest in at least half of the registered statistical parameters.

From table V, we can note the best results in regard to performance for each championship. We extracted the upper limits for the statistical parameters from all the participating teams. These 
Table V. The best statistical results

\begin{tabular}{cccc}
\hline The statistical parameters & Japan 2006 & Turkey 2010 & Spain 2014 \\
\hline FT $\%$ & 80,7 & 80,1 & 77 \\
\hline 2P $\%$ & 57,5 & 56,7 & 58,8 \\
\hline 3P $\%$ & 44.7 & 42,9 & 47,9 \\
\hline R off & 126 & 117 & 135 \\
\hline R def & 249 & 258 & 268 \\
\hline RPG & 40 & 42 & 20,4 \\
\hline APG & 18,8 & 18,2 & 18,1 \\
\hline PFPG & 16,7 & 16 & 12,1 \\
\hline STLPG & 11 & 10,4 & 5,9 \\
\hline BLKPG & 4,9 & 4,9 & 105 \\
\hline PPG & 104 & 92,8 & 9,2 \\
\hline TOPG & 10,8 & 10,4 & 941 \\
\hline
\end{tabular}

\section{Discussions}

The after-the-game statistical information offers the possibility to appreciate if the number of shots taken is adequate and if the efficacy for each player on its position, reported at the shooting-frequency, is optimal.

The statistical draft offers a statistical overview on the team's positive and valuable elements and also on the deficiencies that can be improved during training [6].

After the study we conducted we managed to outline in this paper the model of an ideal high performance team depending on the 13 statistical parameters and on the average height of the players.

Along with the statistical study of the game models, coaches must also ensure:

- the evolution of the fast-break in the modern game of basketball;

- the fast attacks or the transition attacks, the ball movement or the players' movement, the duration and the places from where the baskets were scored;

- the $5 \times 5$ positional attacks, situations/means with center/pivot plays, place for forwards and offensive guards, the movement of the ball and of the players, the shooting spots, the predominance of individual or collective plays;

- the self-defense and the opponent's defense, the expanding of the defense-area, individual and collective plays.

\section{Conclusions}

In conclusion, with an average current percentage (world-wide) of over 34\% for 3-point shots, over $49 \%$ for 2 -point shots and more than $70 \%$ for the free-throw line shots, experts in the field will certainly be looking to improve the technical and tactical practice for the high-level-competition basketball teams, through optimizing the performance model.

The statistical results regarding the other analyzed parameters should be seen as training objective that in order to maintain the progress in the game of basketball.

The average height of the team could play an important role in achieving better performances. A team with a mean-height bigger than the average height for a certain competiton, has more chances to rank higher.

Experts in the field believe that performance is dependent on the total capacity of the player, the bio-psycho-social system result of improving regulatory enforcement functions, morphological, physiological, informational, decisional and psychic regulator system [6].

\section{Reference}

1. Grădinaru C., Miron P. (2005). Studiu asupra parametrilor modelului de joc al echipelor participante la Campionatul European de baschet masculin - Serbia - Muntenegru 2005, Analele UVT, Seria EFS, No.7, pp. 55-59.

2. García J., Sergio J. Ibáñez, Raúl Martinez De Santos, Nuno Leite, Jaime Sampaio (2013). Identifying Basketball Performance Indicators in Regular Season and Playoff Games, Journal of Human Kinetics Section III, Sports Training, vol. 36, pp. 163-170.

3. Gómez M.A., Lorenzo A., Ibáñez S.J., Ortega E., Leite N., Sampaio J. (2010). An analysis of defensive strategies used by home and away basketball teams, Percept Motor Skill, 110(1), pp. 159-166. 4. Trninić S., Dizdar D., Luksić E. (2002). Differences between winning and defeated top quality basketball teams in final tournaments of European club championship, Coll Antropol, 26(2), pp. 521-531

5. Epuran M. (2005). Metodologia cercetării activităţilor corporale, Editura Fest, București.

6. Predescu T., Ghițescu G. (2001). Baschet Pregătirea echipelor de performanţă, Editura Semne.

7.http://www.fiba.com/pages/eng/fa/p/search.html [accessed at 28.10.2016] 